Tomasz Szczygieł

Uniwersytet Śląski w Katowicach e-mail: tomasz.szczygiel@us.edu.pl

ORCID: 0000-0002-7017-0000

DOI: 10.15290/mhi.2020.19.02.21

\title{
Kwestia „ochrony” wolności sumienia i wyznania w toku prac nad kodyfikacją prawa karnego Polskiej Rzeczypospolitej Ludowej 1949-1969
}

\begin{abstract}
Abstrakt
W pracy przedstawiono rozwój regulacji karnoprawnych dotyczących ochrony wolności sumienia i wyznania w PRL w latach 1949-1969. Przedstawiona analiza ukazuje rzeczywistą intencje tych przepisów, a sprowadzającą się do spacyfikowania związków wyznaniowych pod względem ich potencjalnego oddziaływania na opinię publiczną. Nie ulega wątpliwości, że poddane analizie przepisy prawne stanowiły wyraz walki władzy komunistycznej z jedyną po 1944 r. niezależną instytucją, jaką był Kościół katolicki. W pracy uwypuklono również problem ostracyzmu osób związanych z ruchem komunistycznym, który niewątpliwie występował, zwłaszcza po groźbie ekskomuniki wystosowanej przez Watykan w lipcu 1949 r. Tym samym wolność sumienia i wyznania stała się niejako „zakładnikiem” rozwijającej się walki o nowy ustrój państwowy i miejsce w nim związków wyznaniowych.
\end{abstract}

\begin{abstract}
The issue of "protection" of freedom of conscience and religion in the course of work on codification of criminal law of the Polish People's Republic 1949-1969

The paper presents the development of criminal law regulations regarding the protection of freedom of conscience and religion in the Polish People's Republic in 1949-1969. The presented analysis shows the real intentions of these regulations. The communist party wanted to control religious associations in terms of their potential
\end{abstract}


impact on public opinion. There is no doubt that the analyzed regulations were an expression of the struggle of the communist authorities with the only independent institution after 1944, which was the Catholic Church. The work also highlights the problem of the ostracism of people associated with the communist movement, which was undoubtedly present, especially after the threat of excommunication issued by the Vatican in July 1949. As a result of this, freedom of conscience and religion became a kind of "hostage” of the growing struggle for a new state system and the place of religious associations.

Słowa kluczowe: Polska Ludowa, prawo karne, Kościół katolicki, wolność wyznania, wolność sumienia

Key words: Polish People's Republic, criminal law, Catholic Church, freedom of religion, freedom of conscience

\section{Wprowadzenie}

Cechą totalitaryzmów wszelakiej natury jest nie tylko ciągła walka o utrzymanie władzy, tak politycznej jak i ekonomicznej, ale także chęć zawładnięcia umysłami i sumieniami swoich poddanych. Tam bowiem znajduje się „klucz” do całkowitego podporządkowania jednego człowieka drugiemu, a w konsekwencji dopełnienie dokonywanej rewolucji. Dąży się do tego, tak przy pomocy środków ideologicznych, ekonomicznych jak i prawnych.

Rywalizacja o „rząd dusz” między władzą świecką a duchowną jest tak stara jak ludzkość. Władza świecka doskonale zdaje sobie sprawę, że jeżeli sama nie stanie się ostoją religii, to będzie musiała konkurować ze związkami wyznaniowymi. Jednak w ustrojach totalitarnych ta „konkurencja” przybiera formę walki. Nie ma mowy o współdziałaniu, dialogu, wzajemnym poszanowaniu czy oświeceniowym rozdziale. Możliwe są bowiem dwa scenariusze. Pierwszy, polegający na podporządkowywaniu religii i związków wyznaniowych sprawom państwowym, ewentualnie ich marginalizowanie i prześladowanie (np. Rosja bolszewicka, ZSRR, III Rzesza). Drugi, sprowadzający się do podporządkowania struktur państwa konkretnej religii lub związkowi wyznaniowemu (niektóre państwa wyznaniowe Bliskiego Wschodu np. Islamska Republika Iranu). Każde z tych rozwiązań stanowi zaprzeczenie wolności jednostki.

Przedmiotem niniejszej pracy jest odpowiedź na pytanie, z którym z powyższych systemów mieliśmy do czynienia w Polsce Ludowej w latach 1944-1969 oraz jaką rolę pełniło w nim prawo karne, zwłaszcza w kontekście prac nad jego kodyfikacją po II wojnie światowej. Celem niniejszej pracy jest również ukazanie stosunku Kościoła katolickiego do dokonywanych przekształceń 
prawa karnego materialnego w zakresie ochrony wolności sumienia i wyznania na etapie ich powstawania.

\section{Dekret o wolności sumienia i wyznania z 1949 r.}

Dla Juliusza Makarewicza religia była ważnym czynnikiem społecznym, dlatego w interesie zbiorowości, a nie swobody wyznania poszczególnych obywateli, objął w kodeksie karnym z 1932 r. ochroną wierzenia religijne (Rozdział XXVI „Przestępstwa przeciwko uczuciom religijnym” art. 172-174). Warunkiem było, aby przedstawiały one walory społeczne, a więc były przez państwo uznane ${ }^{1}$. Przepisy te miały zapobiegać szkodliwemu oddziaływaniu „szerokich mas”, zarówno wobec sprawców tego rodzaju przestępstw jak i w kierunku wywoływania religijnego indyferentyzmu ${ }^{2}$.

Pod koniec II wojny światowej, deklaracje władz komunistycznych nie wskazywały na wolę walki z Kościołem katolickim i osobami wierzącymi. Wszak Manifest Polskiego Komitetu Wyzwolenia Narodowego z 22 lipca 1944 zapowiadał utrzymanie podstawowych postanowień Konstytucji marcowej, a do takich z pewnością należał art. 114 tego aktu ${ }^{3}$. Było to jednak tylko złudzenie, albowiem $\mathrm{z}$ oczywistych względów tego rodzaju pozycja w państwie Kościoła katolickiego, czy jakiegokolwiek związku wyznaniowego, była niemożliwa do utrzymania, tak z politycznego jak i ideologicznego punktu widzenia.

O zmianie podejścia władz do powyższych kwestii świadczyło już samo jednostronne zerwanie 12 września 1945 r. przez Tymczasowy Rząd Jedności Narodowej Konkordatu z 1925 r. ${ }^{4}$ Propaganda komunistyczna wskazywała jako uzasadnienie tego posunięcia przede wszystkim działalność Watykanu w okresie II wojny światowej $j^{5}$. Przekonywano, że to Watykan zerwał umowę już w grudniu 1939 r, powierzając diecezję chełmińską Niemcowi, biskupowi gdańskiemu Karolowi Marii Splettowi. Jako argument podawano również mianowanie przez papieża administratorem apostolskim diecezji gnieźnieńsko-poznańskiej Niemca Hilariusa Bretingera ${ }^{6}$.

1 J. Makarewicz, Kodeks karny z komentarzem. Lwów 1935, s. 334-335 (dalej: J. Makarewicz, Kodeks karny, wyd. $z 1935$ roku...).

2 Idem, Kodeks karny z komentarzem. Lwów 1938 (eeprint Lublin 2012), s. 442 (dalej: J. Makarewicz, Kodeks karny wyd. $z 1938$ roku (reprint Lublin 2012)).

3 „Wyznanie rzymsko-katolickie, będące religią przeważającej większości narodu, zajmuje w Państwie naczelne stanowisko wśród równouprawnionych wyznań. Kościół Rzymsko-Katolicki rządzi się własnymi prawami. Stosunek Państwa do Kościoła będzie określony na podstawie układu ze Stolicą Apostolską, który podlega ratyfikacji przez Sejm - ustawa z dnia 17 marca 1921 r., Konstytucja Rzeczypospolitej Polskiej (Dz.U. 1921 nr 44, poz. 267).

4 A. Nowicz, Stosunki Kościót-Państwo w Polsce 1944-55 (Szkic zagadnienia), Poznań 1984, s. 15.

5 J. Żaryn, Kościót w PRL, Warszawa 2004, s. 14.

6 I. Kienzler, Kronika PRL 1944-1989, t. 27, Kościół w PRL, Warszawa 2016, s. 14. 
Nagonka na duchowieństwo wzmogła się jeszcze po słynnym liście papieża do biskupów niemieckich z marca 1948 r., w którym Pius XII miał rzekomo sugerować możliwość anulowania ustaleń poczdamskich w części dotyczącej granicy na Odrze i Nysie Łużyckiej ${ }^{7}$. Zerwanie konkordatu stwarzało - jak słusznie zauważył Jan Żaryn - pustkę prawną, którą należało czymś wypełnić. W grę wchodziła oczywiście nowa umowa międzynarodowa, albo układ krajowy z Episkopatem Polski ${ }^{8}$. Środkami do celu, jakim miało być ułożone na nowo stanowisko Kościoła katolickiego w państwie ludowym, były szykany, nagonka, działania zmierzające do podziału księży na tych „pozytywnych” („księża patrioci”) i „reakcyjnych" oraz rozbicie katolickich stronnictw politycznych ${ }^{10}$.

Fakty powyższe miały swoje przełożenie na prawo karne, które niewątpliwie miało pomóc w złamaniu solidarności duchowieństwa i zmuszenia hierarchów do zawarcia nowego układu. Dnia 5 sierpnia 1949 r. został bowiem wydany dekret o ochronie wolności sumienia i wyznania (dalej: „Dekret sierpniowy”) ${ }^{11}$. Akt ten wszedł w życie w dość osobliwych okolicznościach, tak wewnętrznych jak i międzynarodowych. Jeśli chodzi o te pierwsze, to proces kodyfikacji prawa karnego materialnego utknął wówczas w martwym punkcie ${ }^{12}$. Ministerstwo Sprawiedliwości oczekiwało na decyzje najwyższych czynników rządowych i partyjnych w tym zakresie. Decyzja zapadła dopiero we wrześniu 1950 r., czyli po zdemaskowaniu i likwidacji odchylenia prawicowo-nacjonalistycznego w kierownictwie partii (W. Gomułka, M. Spychalski). Stało się ono pretekstem do nasilenia represji ${ }^{13}$. Co jednak chyba najistotniejsze, 3 lipca $1949 \mathrm{r}$. $\mathrm{w}$ katedrze w Lublinie, „miało miejsce wydarzenie, które jawnie godziło w materialistyczny światopogląd propagowany przez władze"14. Podczas ingresu biskupa Piotra Kałwy, wierni twierdzili, że na obrazie Matki Boskiej zauważyli jakąś ciecz, która wydawała się krwawymi łzami ${ }^{15}$. Napływ pielgrzymów oraz

\footnotetext{
J. Żaryn, op. cit., s. 14.

Ibidem.

Ibidem, s. 21.

10 Co najmniej od jesieni 1948 r. środowisko „Dziś i Jutro” (od 1952 „PAX”), kojarzone z Bolesławem Piaseckim, „(...) aktywnie współtworzyło zdominowaną przez komunistów Polskę”, ibidem, s. 47.

11 (Dz.U. $1949 \mathrm{nr}$ 45, poz. 334). Zobacz także A. Skoczeń, Wolność sumienia i wyznania w świetle orzecznictwa Sąu Najwyższego w Polsce Ludowej. Rozprawa doktorska obroniona w 2019 r. w Akademii Leona Koźmińskiego w Warszawie, napisana pod kierunkiem Prof. ALK dr hab. Marzeny Dyjakowskiej; sygn. 208. DR. Sko.2019, s. 124-169 (dalej: A. Skoczeń, op. cit.).

12 D. Maksimiuk, Krótka historia długo obowiązującego dekretu, czyli o tzw. małym kodeksie karnym. „Miscellanea Historico-Iuridica” 2010, t. IX, s. 87.

13 Uchwała Prezydium Rządu z dnia 27 września 1950 r., w sprawie opracowania nowych kodeksów Polski Ludowej - karnego i cywilnego (Mon. Pol. 1950, nr A-106, poz. 1339); K. Grzybowski, Reform and Codification of Polish Laws, "The American Journal of Comparative Law” 1958, t. 7, nr 3, s. 395-396.

14 I. Kienzler, op. cit., s. 18.
}

15 Ibidem. 
rozprzestrzeniające się po Polsce przekonanie o rzekomym cudzie w miejscu kaźni polskich patriotów (na zamku w Lublinie mieściło się więzienie podległe najpierw władzom sowieckim, a potem Urzędowi Bezpieczeństwa), było dla władz zjawiskiem niebezpiecznym.

Jeśli chodzi o aspekt międzynarodowy, to również w lipcu tego samego roku papież Pius XII wydał dekret, w którym zagroził ekskomuniką wszystkim katolikom należącym do partii komunistycznych lub z nimi współpracującym ${ }^{16}$. I chociaż - jak powszechnie wiadomo - katolicy nie byli w partii mile widziani, to jednak komuniści mieli przecież rodziny, przyjaciół i znajomych, którzy nie tylko deklarowali, ale również praktykowali przynależność do Kościoła katolickiego. Taka sytuacja musiała stawiać obie strony w trudnym położeniu. To mogło z kolei powodować pojawienie się ostracyzmu społecznego, czyli jak trafnie podkreślał Juliusz Makarewicz, „najbardziej klasycznego środka zabezpieczającego"17.

W takich okolicznościach został wydany „dekret sierpniowy”. I chociaż akt ten $\mathrm{w}$ art. $15^{18}$ nie wskazywał wyraźnie w jakim zakresie uchyla moc obowiązującą dotychczasowych przepisów, to jednak najprawdopodobniej chodziło w pierwszej kolejności o art. $173^{19} \mathrm{k} . \mathrm{k}$ z 1932 roku oraz art. 30-32 m.k.k ${ }^{20}$. Dyskusyjny był natomiast los art. $172 \mathrm{k} . \mathrm{k} \mathrm{z} 1932 \mathrm{roku}^{21}$. Z jednej bowiem strony wskazywał on na wiarę w istnienie Najwyższej Istoty (Boga), ale z drugiej nie poddawał penalizacji ateizmu. Makarewicz twierdził wyraźnie, że „Bluźnienie Bogu nie jest identyczne z zaprzeczeniem istnienia Boga. Manifestacja ateizmu podana przedmiotowo, bez brutalnych wystąpień przeciw wierze $\mathrm{w}$ istnienie Boga, nie jest bluźnieniem, gdyż nie zawiera ani czynnika zniewagi dla Najwyższej Istoty, pojętej abstrakcyjnie, ani zamiaru dotknięcia uczuć religijnych u innych" 22 . To znamienna okoliczność, albowiem władze komunistyczne uzasadniały wydanie dekretu koniecznością ochrony osób bezwyznaniowych,

16 Ibidem.

17 J. Makarewicz, Prawo karne i prawa obywatela. (Odczyt wygłoszony w dniu 20 stycznia 1936 r. w Auli Uniwersytetu J. K. we Lwowie w czasie Akademii w związku z 275. rocznicą założenia tegoż Uniwersytetu) s. 101 (http://www.khpp.wpia.uj.edu.pl/documents/106750129/137607143/Juliusz +Makarewicz\%2C+Prawo+karne+i+prawa+obywatela\%2C+Lwów+1936.pdf/199928e0-6385-44a7 -ba0e-a51d568af32b, (10.08.2019).

18 „Uchyla się moc prawną przepisów kodeksu karnego z 1932 r., i przepisów dekretu z dnia 13 czerwca 1946 r., o przestępstwach szczególnie niebezpiecznych w okresie odbudowy Państwa (Dz.U. R. P. nr 30, poz. 152) w zakresie unormowanym przepisami niniejszego dekretu”.

19 „Kto publicznie lży lub wyszydza uznane prawnie wyznanie lub związek religijny, jego dogmaty, wierzenia lub obrzędy, albo znieważa przedmiot jego czci religijnej lub miejsce przeznaczone do wykonywania jego obrzędów, podlega karze więzienia do lat 3".

20 S. Pławski, Uwagi o dekrecie z 5 sierpnia 1949 r., s. 2-4 (AAN.MS. sygn. 285/1829).

21 „Kto publicznie Bogu bluźni, podlega karze więzienia do lat 5”.

22 J. Makarewicz, Kodeks karny, wyd. z 1935..., s. 334. 
czy ateistów w ogóle ${ }^{23}$. Temu miało służyć podkreślenie w nowych przepisach karnych znamienia „bezwyznaniowości” 24 .

Stanisław Pławski opiniujący przepisy tego dekretu - co jednak warto podkreślić już po ich opublikowaniu (podkr. T. Sz.) - wskazał, że dekret ten był jedynym ówczesnym aktem prawnym o podwójnym konstytucyjno-karnym charakterze $^{25}$. Trafnie zauważył, że art. $8^{26}$ dekretu niewiele miał wspólnego z ochroną wolności sumienia i wyznania, a stanowił przestępstwo przeciwko państwu, na równi z art. 93-95 k.k z 1932 r. oraz art. 85 i 86 k.k.W.P²7.

Jednak to nie rzekoma ochrona bezwyznaniowców czy nawet państwa zasługuje na szczególną uwagę w dekrecie z 5 sierpnia 1949 r., ale ochrona członków partii komunistycznej i ich rodzin, w kontekście zagrożenia ekskomuniką. Wystarczy bowiem zwrócić uwagę na art. 2 do 4 dekretu $^{28}$, w których jest mowa m.in. o „ograniczaniu obywatela w jego prawach ze względu na jego przynależność wyznaniową, przekonania religijne lub bezwyznaniowość (art. 2) $)^{29 ”, ~ „ z m u s z a n i u ~ l u b ~ p o w s t r z y m y w a n i u ~ o d ~ u d z i a ł u ~ w ~ c z y n n o s ́ c i a c h ~ l u b ~}$ obrzędach (art. 3) ${ }^{30}$ ”, oraz „odmawianiu udostępnienia obrzędu lub czynności religijnej z powodu działalności lub poglądów politycznych, społecznych albo naukowych (art. 4)".

23 „Rzeczpospolita Polska poręcza wszystkim obywatelom wolność sumienia i wyznania” („Dekret sierpniowy").

24 „Kto ogranicza obywatela w jego prawach ze względu na jego przynależność wyznaniową, przekonania religijne lub bezwyznaniowość, podlega karze więzienia do lat 5” (art. 2); „Kto publicznie lży, wyszydza lub poniża grupę ludności albo poszczególną osobę z powodu przynależności wyznaniowej, przekonań religijnych lub bezwyznaniowości, podlega karze więzienia do lat 5 lub aresztu’ (art. 7).

25 S. Pławski, op. cit., s. 2.

26 „Kto nadużywa wolności wyznania i sumienia w celach wrogich ustrojowi Rzeczypospolitej Polskiej, podlega karze więzienia od lat trzech".

27 S. Pławski, op. cit., s. 3.

28 „Kto w jakikolwiek sposób zmusza inną osobę do udziału w czynnościach lub obrzędach religijnych albo ją od tego udziału bezprawnie powstrzymuje, podlega karze więzienia do lat 5” (art. 3); „Kto nadużywa wolności wyznania, odmawiając udostępnienia obrzędu lub czynności religijnej z powodu działalności lub poglądów politycznych, społecznych albo naukowych, podlega karze więzienia do lat 5" (art. 4).

29 Jak ustalił A. Skoczeń, Sąd Najwyższy w wyroku z dnia 2 kwietnia 1963 r., sygn.. II K 666/60, uniewinnił księdza Stanisława P. od zarzutu, że jako katecheta szkoły podstawowej zabronił dzieciom udziału w pogrzebie działacza społecznego będącego ateistą, przyjmując za twierdzeniami obrony, że nie uczynił tego kategorycznie, a jedynie stwierdził, że „dzieci nie powinny pójść na pogrzeb, bo zmarły był niewierzący, ale kto chce, może pójść" cyt. za: A. Skoczeń, op. cit.

30 Szerzej zob. wyrok SN z dnia 10 maja 1963 r., I K 195/62, LEX nr 170907, cyt. za: A. Skoczeń, op. cit., s. 139. 
Z kolei w kontekście „cudu lubelskiego” należy postrzegać art. 9 dekretu, choć czyn ten stanowił sui generis oszustwo polegające na wyzyskaniu czyjejś łatwowierności w celu uzyskania korzyści majątkowej ${ }^{31}$.

Władza ewidentnie obawiała się, aby Kościół nie mobilizował wiernych, poprzez ich rzekomą „łatwowierność lub szerzenie fałszywych wiadomości”32. Wszak komisja kościelna, która badała „cud lubelski”, ani nie potwierdziła ani nie zaprzeczyła, że był to cud $^{33}$. Równolegle władze stosowały represje finansowe (grzywny) w postaci odpowiedzialności za wykroczenia z ustawy o zgromadzeniach z 11 marca 1932 r., w tym przede wszystkim te z tytułu organizacji zgromadzeń wbrew przepisom (art. 25) ${ }^{34}$. Do paraliżowania działalności Kościoła katolickiego służyły ponadto przepisy ustawy z dnia 31 stycznia $1961 \mathrm{r}$., o łączności ${ }^{35}$ (tzw. megafonizacja kościołów) oraz o odznakach i mundurach $z 2$ października 1935 r., na podstawie której penalizowano wywieszanie flag w barwach biało-żółtych ${ }^{36}$.

Niezależnie od tego, czy chodziło o rzekomą ochronę bezwyznaniowców, czy o rzekome zaangażowanie polityczne Kościoła katolickiego, przepisy „dekretu sierpniowego" oraz normy karno-administracyjne, były wyrazem walki o nowy ustrój i relacje w obrębie społeczeństwa.

\section{Episkopat o projekcie kodeksu karnego z 1963 r.}

Chociaż dekret z 5 sierpnia 1949 r. wciąż obowiązywał, to w Ministerstwie Sprawiedliwości trwały prace nad całościowym kodeksem karnym PRL. Zmieniony po 1956 r. Zespół Prawa Karnego Materialnego Komisji Kodyfikacyjnej przy Ministrze Sprawiedliwości przygotował na początku lat 60. kolejną jego

31 „Kto, nadużywając wolności wyznania w celu osiągnięcia korzyści osobistej, majątkowej lub innej, wyzyskuje łatwowierność ludzką przez szerzenie fałszywych wiadomości lub wprowadza w błąd inne osoby przez oszukańcze lub podstępne czynności, podlega karze więzienia” (art. 9); zob. także A. Skoczeń, op. cit., s. 126, 136-137.

32 „Ks. W. Forkiewicz został skazany na rok więzienia za to, że w okresie od 1 stycznia 1949 r. w Lublinie rozpowszechniał fałszywe wiadomości, które mogły wyrządzić istotną szkodę interesom państwa. Duchowny informował o cudzie, który miał miejsce w katedrze lubelskiej dnia 3 lipca 1949 r., cyt. za: A. Skoczeń, op. cit., s. 126.

33 I. Kienzler, op. cit., s. 18.

34 Ustawa z dnia 11 marca 1932 r., o zgromadzeniach (Dz.U. 1932 nr 48, poz. 187), zmieniona Dekretem z dnia 18 sierpnia 1949 r., o zmianie niektórych przepisów o zgromadzeniach (Dz.U. nr 49, poz. 369) - szerzej. zob. Łysko M., Kolegia karno-administracyjne w walce z Kościołem katolickim $w$ Polsce (1956-1970), „Czasopismo Prawno-Historyczne” 2007, z. 1, s. 138-142.

35 (Dz.U. $1961 \mathrm{nr}$ 8, poz. 48).

36 M. Łysko, op. cit., s. 143-144. 
wersję, która stała się przedmiotem bardzo szerokiej dyskusji publicznej ${ }^{37}$. Warto podkreślić, że projekt ten - nazywany także "Projektem Sawickiego" - powstał w innej rzeczywistości prawnej niż „dekret sierpniowy”. Otóż obowiązywał już wówczas art. 70 Konstytucji PRL z 1952 r. o następującej treści: „Polska Rzeczpospolita Ludowa zapewnia obywatelom wolność sumienia i wyznania. Kościół i inne związki wyznaniowe mogą swobodnie wypełniać swoje funkcje religijne. Nie wolno zmuszać obywateli do niebrania udziału w czynnościach lub obrzędach religijnych. Nie wolno też nikogo zmuszać do udziału w czynnościach lub obrzędach religijnych (1). Kościół jest oddzielony od państwa. Zasady stosunku państwa do kościoła oraz sytuację prawną i majątkową związków wyznaniowych określają ustawy (2). Nadużywanie wolności sumienia i wyznania dla celów godzących w interesy Polskiej Rzeczypospolitej Ludowej jest karane $(3)^{38}$. Jak trafnie zauważył Ludwik Dembiński, od tej pory nie mogło być wątpliwości, że prawo do wolności sumienia i wyznania nie istnieje samo przez się, lecz to PRL była jego źródłem ${ }^{39}$. To PRL „zapewniała” jego istnienie, zakres i przestrzeganie. To z kolei implikuje kolejny wniosek, że Kościół katolicki i inne związki religijne miały pełnić wyłącznie „funkcję religijną”. Co więcej, co również trafnie dostrzegł L. Dembiński, z konstytucyjnego zaka$\mathrm{zu}$ „zmuszania” do uczestniczenia (nieuczestniczenia) ograniczał się do sfery religijnej.

W takiej sytuacji konstytucyjno-prawnej, pomimo wielu wypowiedzi na temat projektu k.k., trudno doszukać się krytyki ze względu na ochronę wolności sumienia i wyznania oraz warunków karalności przerywania ciąży. Przyczyny mogły być dwie, a więc powszechna ich akceptacja, lub obawa przed ich oceną,

37 Przykładowo należy wskazać na: Rozpoczyna się publiczna dyskusja nad projektem nowego kodeksu karnego, „Express Wieczorny” 1963, nr 15, s. 1-2; Projekt nowego kodeksu karnego wchodzi pod publiczna dyskusję, „Trybuna Ludu” 1963, nr 18, s. 3; J. Kolczyński, Projekt kodeksu karnego. Sześć pytań, „Prawo i Życie” 1963, nr 2, s. 1; S. Reperowicz, Obywatel w cieniu paragrafów, „Żołnierz Wolności” wyd. A z 13 marca 1963 r. nr 61, s. 3; Lepiej niech teraz nie śpiq̨... Spór o paragraf, „Sztandar Młodych”, nr 49, s. 3; W. Podsiadło, Nad projektem kodeksu karnego (2) - paragrafy i życie, „Głos Szczeciński” 1963, nr 86, s. 3; Projekt kodeksu karnego w ocenie przedstawicieli wymiaru sprawiedliwości Łodzi i województwa. Narada w KW PZPR, „Głos Robotniczy” 1963, nr 78, s. 2; M. Rybicki, Informacja o stanie prac kodyfikacyjnych i o przebiegu dyskusji nad projektem kodeksu karnego (do użytku wewnętrznego), s. 10-11 - AAN, MS, sygn. 285/1792; J. Olszewski, Blaski i nędze kodyfikacji Zasady kodeksu i logika życia, „Prawo i Życie” (dalej: PiŻ) 1963 r., nr 3, s. 1-3; K. Mioduski, Technika, kodyfikacja a moda, PiŻ 1963, nr 5, s. 3-4; A. Podgórecki, Krytyka metodologicznych założeń projektu kodeksu karnego, „Państwo i Prawo” 1963, nr 4, s. 670; M. Mazur, ZPP a dyskusja nad projektem k.k. PiŻ 1963, nr 4, s. 1-2.

38 Konstytucja Polskiej Rzeczypospolitej Ludowej uchwalona przez Sejm Ustawodawczy w dniu 22 lipca 1952 r. (Dz.U 1952 nr 33, poz. 232). Na mocy art. 1 pkt 40 ustawy z dnia 10 lutego 1976 r. o zmianie Konstytucji Polskiej Rzeczypospolitej Ludowej (Dz.U. 1976 nr 5, poz. 29) skreślono art. 70 pkt 3, stanowiący o karalności nadużywania wolności sumienia i wyznania dla celów godzących w interesy Polskiej Rzeczypospolitej Ludowej.

39 L. Dembiński, Prawo i władza. „Niezależna Oficyna Wydawnicza” (Przedruk z „Aneks” 1979, nr 20), s. 16. 
zwłaszcza w kontekście art. 70 ust. 3 konstytucji w związku z odpowiednimi przepisami „Dekretu sierpniowego” (art. 3, art. 4, art. 8 i art. 9).

Słów krytyki w tym względzie nie szczędził za to Episkopat Polski. Dla hierarchów Kościoła katolickiego nie do przyjęcia był art. 203 projektu ${ }^{40}$ regulujący przestępstwo przerwania ciąży bez zgody kobiety. A contrario oznaczało to bowiem legalność przerywania ciąży za jej zgodą. Według Episkopatu, takie podejście było sprzeczne nie tylko z prawem naturalnym, ale także zasadami moralności chrześcijańskiej ${ }^{41}$. Jak bowiem podkreślił bp Zygmunt Choromański ${ }^{42}$ : „kobieta ze swojej natury i charakteru powołana jest do tego, by utrzymać rodzaj ludzki. Jest sprzeczne z naturą, by po zajściu w ciążę mogła sama usuwać, przerywać ciążę lub inne osoby do tego upoważniać”33. Sekretarz Episkopatu zaznaczył ponadto - dość sugestywnie - że „inne ustawodawstwa - nie wyłączając NRD i ZSRR- nie dopuszczają zabiegu przerwania ciąży, poza wyjątkowymi przypadkami ${ }^{44}$. Z tych względów, w imieniu Episkopatu, opowiedział się za odstąpieniem od projektowanego przepisu i przyjęciem uchylonych art. 231, 232 i 233 k.k. z 1932 r. ${ }^{45}$

Najwięcej zastrzeżeń wzbudził jednak rozdział XIX projektu poświęcony przestępstwom przeciwko wolności sumienia i wyznania ${ }^{46}$. W ocenie Episkopatu projekt - podobnie jak dekret z 1949 r. - odchodził całkowicie od założeń k.k. z 1932 r., albowiem nie traktował już religii jako „wartości społecznej samej w sobie”, ale jedynie jako „fakt społeczny”, licząc się po prostu z tym, że ludzie ją wyznają i nic poza tym ${ }^{47}$. Co więcej, w ocenie hierarchów kościelnych, takie podejście ustawodawcy oznaczało nie tyle wolę pozbawienie religii

40 „Kto dokonuje zabiegu przerwania ciąży bez zgody kobiety, podlega karze pozbawienia wolności od 6 miesięcy do lat 5 ( $\$ 1$ ). Jeżeli kobieta nie ukończyła 16 lat, prócz jej zgody wymagana jest również zgoda rodziców, opiekuna lub władzy opiekuńczej (\$2). Jeżeli kobieta, wskutek choroby psychicznej lub niedorozwoju psychicznego, pozbawiona jest całkowicie lub w znacznym stopniu zdolności rozpoznania znaczenia czynu lub kierowania swym postępowaniem, zamiast jej zgody wymagana jest zgoda rodziców, opiekuna lub władzy opiekuńczej (\$3)” - Komisja Kodyfikacyjna przy Ministrze Sprawiedliwości, Projekt kodeksu karnego. Warszawa 1963, s. 41 (dalej: Projekt kodeksu karnego 1963...).

41 Pismo Sekretarza Episkopatu Polski bp Zygmunta Choromańskiego z dnia 9 maja 1963 r. do ministra sprawiedliwości Mariana Rybickiego w sprawie uwag do projektu kodeksu karnego, s. 2 (dalej: Pismo bp. Z. Choromańskiego...) - AAN, MS, sygn. 564.

42 Jeden z trzech sygnatariuszy porozumienia „O niektórych warunkach życia i działalności Kościoła katolickiego w Polsce” podpisanego 14 kwietnia 1950 r. przez przedstawicieli Kościoła katolickiego i władze komunistyczne. To „porozumienie” było efektem realizacji zaleceń J. Stalina odnośnie do konieczności dokonania rozłamu w Kościele katolickim (tzw. księża patrioci) oraz zakrojonej na szeroką skalę nagonki, szantażu i nacisku na osoby i instytucje związane z Kościołem katolickim A. Nowicz, op. cit., s. 40-41; A. Skoczeń, op. cit., s. 86-87.

43 Ibidem.

44 Ibidem.

45 Ibidem.

46 Projekt kodeksu karnego 1963..., s. 36-37.

47 Pismo bp. Z. Choromańskiego..., s. 3. 
ochrony, co wręcz zapewnienia obywatelom rzekomej „wolności od religii”" A contrario oznaczało to, że nowa władza postrzegała sytuację społeczną i stan prawny okresu międzywojennego jako zaprzeczające tej wolności i wymagające zmiany, pod szyldem „ochrony bezwyznaniowców”.

Kolejny zarzut pod adresem projektu sprowadzał się do próby „ubezwłasnowolnienia", a wręcz rozkładu związków wyznaniowych, poprzez przepisy pozbawiające go możliwości decydowania o tym kto jest, a kto nie jest jego członkiem. I to wszystko rzekomo w celu obrony przed „dyskryminacją religijną", tak bezpośrednio zainteresowanych jak i ich „bliskich” (art. $175 \$ 1)^{49}$. W ocenie Episkopatu takie szerokie uregulowanie mogło tylko „pogłębić waśnie i fanatyzm na tle wyznaniowym" ${ }^{\text {. }}$.

Hierarchom kościelnym trudno było również przejść obojętnie obok „zupełnej nowości” projektu, jakim był art. 176, wprowadzający karalność „bojkotu społecznego z powodu przekonań religijnych, przynależności wyznaniowej lub bezwyznaniowość" ${ }^{51}$. W związku z tym sekretarz Episkopatu Zygmunt Choromański zapytał ministra sprawiedliwości: „Jak bowiem ustalić różnicę między namawianiem do bojkotu, a przestrzeganiem przed wdawaniem się z nieodpowiednimi ludźmi? Czy wobec tego kapłanowi nie będzie wolno przestrzegać wiernych przed ludźmi, którzy przychodzą do nich z propagandą wrogą Kościołowi? Czy nie będzie wolno kapłanowi powiedzieć wiernym, by nie chodzili do świątyni innego wyznania lub wyjaśnić im, że w przypadku tzw. Kościoła narodowego - podszywa się on tylko pod nazwę „katolicki”?52 Oczywiście w podtekście chodziło o osoby zaangażowane politycznie.

Retoryczne $\mathrm{w}$ gruncie rzeczy pytania bp. Choromańskiego, a dotyczące art. 176 projektu, były jedynie wstępem do znacznie mocniejszych stwierdzeń. Najwięcej emocji wzbudził bowiem projektowany przepis art. 178, który pod groźbą kary zmuszał związki wyznaniowe do dopuszczania do czynności i obrzędów religijnych osoby, które na to nie zasługują lub ich udział zakazują przepisy religijne. Choromański wymienił m.in. ateistów, ekskomunikowanych i osoby „mające wrogie dla danego wyznania poglądy" ${ }^{53}$. Posługując się argu-

48 Ibidem

49 Ibidem. „Kto z powodu przekonań innej osoby w sprawach religii, jej przynależności wyznaniowej lub bezwyznaniowości stosuje wobec tej osoby lub jej bliskiego dyskryminację, w szczególności przez to, że odmawia wykonania czynności, do której jest zobowiązany, zwleka z jej wykonaniem lub przy jej wykonaniu daje pierwszeństwo innym osobom, podlega karze pozbawienia wolności do lat 3" - Projekt kodeksu karnego 1963..., s. 36.

50 Pismo bp. Z. Choromańskiego..., s. 4.

51 „Kto z powodu przekonań innej osoby w sprawach religii, jej przynależności wyznaniowej lub bezwyznaniowości organizuje bojkot społeczny tej osoby lub jej bliskiego albo nawołuje lub namawia do takiego bojkotu, podlega karze pozbawienia wolności do lat 5" (art. 176) - Projekt kodeksu karnego 1963..., s. 36.

52 Pismo bp. Z. Choromańskiego..., s. 4.

53 Ibidem, s. 5. 
mentem ad absurdum wskazał: „Projekt k.k. więc uważa, że osób nie można zmuszać (podkr. oryginalne - T. Sz) do udziału w czynnościach i obrzędach religijnych, bo jest to karane /art. 177 projektu k.k/, ale duchownych można zmuszać (podkr. oryginalne - T. Sz) do dopuszczania do czynności i obrzędów /art. $178 \$ 1$ projektu k.k./ osób np. ekskomunikowanych i do udzielania posług religijnych zmarłym /art. $178 \$ 2$ projektu k.k./, którzy swym postępowaniem za życia sami wykluczyli się ze społeczności religijnej"54.

Sekretarz Episkopatu nie poprzestał jednak tylko i wyłącznie na argumencie logicznym wskazującym na niedorzeczność regulacji. Przełożył go również na zarzut bezpośrednio pod adresem PZPR o następującej treści: „Ciekawe, że brak przepisu analogicznego np. odnośnie do dopuszczania do zebrań partyjnych; nie ma przepisu, który zmuszałby kierownictwo partii do dopuszczenia do udziału w zebraniach osób, które np. zostały wydalone z partii z powodu jakichś przewinień, a logicznie biorąc w konsekwencji kierownictwo winno być zmuszone tak jak duchowny, nie tylko do dopuszczenia do udziału osoby wydalonej w zebraniu, ale nadto do udzielania „ostatniej posługi” przez udział członków partii w pogrzebie wydalonego członka partii”"55.

Nie mniejsze kontrowersje w ocenie Episkopatu wzbudzały art. $180^{56}$ i $181^{57}$ projektu. Ten pierwszy bp Choromański określił mianem „fanatycznego”, albowiem przewidywał karę wyższą nawet od zbrodni publicznego nawoływania do zbrodni przeciwko pokojowi i ludzkości ${ }^{58}$. Ten drugi z kolei, był nie do zaakceptowania ze względu na trudne do określenia pojęcie „zabobon” ${ }^{59}$. Przepis ten stanowił odpowiednik art. 9 dekretu o wolności sumienia i wyznania.

Powyższe rozwiązania stanowiły dla Episkopatu przykład zupełnego niezrozumienia rzeczywistości. Otóż z całokształtu przepisów projektu kodeksu można było bowiem wysnuć wniosek, że przed PRL stoi perspektywa nasilenia się waśni narodowościowych i religijnych rodem ze średniowiecza ${ }^{60}$.

54 Ibidem.

55 Ibidem, s. 6.

56 „Kto, pełniąc funkcję religijną, nadużywa wolności sumienia i wyznania przez to, że w czasie publicznego obrzędu religijnego: znieważa lub wyszydza Naród Polski, Państwo Polskie lub ustrój Polskiej Rzeczypospolitej Ludowej; rozgłasza wiadomości nieprawdziwe mogące wywołać niepokój publiczny lub wyrządzić inną istotną szkodę interesowi publicznemu; nawołuje do nieposłuszeństwa lub przeciwdziałania ustawie albo rozporządzeniu, zarządzeniu lub uchwale organu władzy lub administracji państwowej, wydanych na podstawie ustawy i w jej wykonaniu; nawołuje do przestępstwa lub je pochwala, podlega karze pozbawienia wolności od roku do lat 10" - Projekt kodeksu karnego 1963..., s. 37.

57 „Kto, wyzyskując zabobon lub nadużywając łatwowierności ludzkiej w sprawach łączących się $\mathrm{z}$ religią, przez wprowadzenie w błąd innych osób doprowadza do powstania zbiegowiska lub innej sytuacji mogących wywołać niepokój publiczny, podlega karze pozbawienia wolności do lat 5” Ibidem.

58 Pismo bp. Z. Choromańskiego..., s. 6.

59 Ibidem.

60 Ibidem, s. 8. 
Jan Olszewski napisał: „fanatyzm religijny znajduje się w oczywistym odwrocie. W pokoleniu ludzi dziś trzydziesto- lub dwudziestoletnich kwestia przekonań religijnych lub ich braku z pewnością nie jest najistotniejszym problemem (...) w pokoleniu następnym będzie ona $\mathrm{z}$ pewnością grała rolę jeszcze mniejszą. Powszechny postęp oświaty wypiera coraz bardziej ciemnotę i nic nie wskazuje na to, aby w przyszłości proces ten miał ulec opóźnieniu czy wręcz odwróceniu. Skąd więc ta apokaliptyczna wizja społeczeństwa rozdzieranego konfliktami przeniesionymi w naszą epokę jak gdyby wprost ze średniowiecza? ${ }^{61}$ "

I choć odpowiedź hierarchii kościelnej była negatywna, co do możliwości ziszczenia się tej apokaliptycznej wizji, to i tak tego rodzaju kontrowersje i stanowisko Episkopatu były znamienne. $Z$ jednej bowiem strony obnażały prawdziwą intencję partii w przygotowywaniu przepisów prawa karnego, rzekomo w celu ochrony „wolności i sumienia i wyznania”, a z drugiej, były przestrogą dla czynników politycznych przed ewentualnym wprowadzeniem ich w życie, w kontekście konsekwencji, jakie mogą wywołać.

Projekt ostatecznie upadł w dość podejrzanych - jak sugeruje Janusz Kochanowski - okolicznościach politycznych ${ }^{62}$. Na pewno jednak tego przyczyną nie były przepisy wymierzone w Kościół katolicki i inne związki wyznaniowe, gdyż im trudno byłoby zarzucić „niedojrzałość polityczną”. Jedynym, który je publicznie skrytykował był Jan Olszewski, choć z innego niż Episkopat punktu widzenia $^{63}$. Problem karnoprawnej „ochrony” wolności sumienia i wyznania miał powrócić przy okazji prac nad kolejną wersją projektu kodeksu karnego PRL.

\section{Projekt kodeksu karnego z 1968 r.}

Projekt kodeksu karnego z 1968 r., który nie bez przesady można nazwać „Projektem Andrejewa”, był pod wieloma względami wyjątkowy. Przede wszystkim była to już trzecia wersja kodeksu karnego PRL, od czasu oficjalnego przystąpienia do prac kodyfikacyjnych w 1950 r. Ponadto jego opracowanie zbiegało się z rocznicą 25-lecia Polski Ludowej. Tym razem czynniki polityczne a w ślad za nimi Zespół Prawa Karnego Materialnego Komisji Kodyfikacyjnej przy Ministrze Sprawiedliwości, podeszły inaczej do problematyki kodyfikacji prawa karnego niż to miało miejsce dotychczas. W pierwszej kolejności został opracowany dokument pt. Założenia społeczno-polityczne k.k.”, który został

61 J. Olszewski, K.k., i fantazja. „Nowa Kultura” 1963, s. 1.

62 J. Kochanowski, Redukcja odpowiedzialności karnej (Analiza i ocena założeń kodeksu karnego z 1997 na tle innych polskich kodyfikacji karnych). Komentarz, Warszawa 2000, s. 9; idem, Przeciwko pośpiesznej kodyfikacji karnej. „Palestra” 1990, t. 34, nr 8-9, s. 13.

63 J. Olszewski, K.k., i fantazja..., 1-3. 
zaakceptowany przez partię ${ }^{64}$. Następnie referenci opracowali projekt wraz $z$ obszernym uzasadnieniem ${ }^{65}$. Przepisy projektu były konsultowane $z$ najwyższymi czynnikami rządowymi i politycznymi PRL, a dyskusja publiczna nad projektem miała taki przebieg, aby nie przeszkadzała w uchwaleniu nowego kodeksu ${ }^{66}$ Z całokształtu okoliczności należy wnioskować, że ten projekt po prostu już nie mógł upaść.

Podejście do problematyki ochrony wolności sumienia i wyznania, a w zasadzie stosunku do Kościoła katolickiego i innych związków religijnych, pozostało niezmienne w tym projekcie, co też dobitnie stwierdzono w oficjalnym jego uzasadnieniu w sposób następujący: „Norma art. $200^{67}$ sankcjonuje zasadę rozdziału kościoła od Państwa. Liczy się ona $\mathrm{z}$ faktem, że pewne środowiska wśród hierarchii kościelnej, nie chcąc pogodzić się z obecną rzeczywistością i podporządkować zasadzie rozdziału kościoła od Państwa, nadużywają zagwarantowanych swobód konstytucyjnych w zakresie funkcji i czynności religijnych ze szkodą dla interesów Państwa Ludowego"68. Zwraca na siebie uwage już sama pisownia słowa „Państwo” w konfrontacji z pojęciem „kościół”, które ewidentnie odnosiło się do Kościoła katolickiego.

Takie podejście spotkało się ponownie z reakcją Episkopatu Polski ${ }^{69}$. Wytknął on projektodawcom brak karalności „publicznego lżenia lub wyszydzania prawnie uznanego wyznania, jego dogmatów, wierzeń lub obrzędów”, które dotychczas było objęte art. 173 k.k. z 1932 r. W ocenie hierarchów Kościoła katolickiego, art.199 projektu ${ }^{70}$, będący odpowiednikiem art. 7 „Dekretu sierpniowego" - był pod tym względem niewystarczający ${ }^{71}$.

64 Wstęp do Założeń społeczno-politycznych k.k.(Wersja III), s. 1 - (AAN, MS, sygn. 285/1844).

65 Projekt kodeksu karnego oraz przepisów wprowadzających kodeks karny. Warszawa 1968 (dalej: Projekt $z 1968$ roku...).

66 Protokół z konferencji pod przewodnictwem Prezesa Rady Ministrów Józefa Cyrankiewicza odbytej $w$ dniu 3 stycznia 1968 roku $w$ sprawie omówienia i rozstrzygnięcia nieuzgodnionych problemów projektu kodeksu karnego (poufne), s. 1-2 (AAN, PZPR Komitet Centralny, sygn. XI/908); Protokót z 35 posiedzenia Komisji Wymiaru Sprawiedliwości Sejmu Polskiej Rzeczypospolitej Ludowej z dnia 19 kwietnia 1968 roku, s. 7 (AAN, Sejm PRL - IV Kadencja 1965-1969. Protokóły komisji sejmowych. Tom LXXXI. Komisja Wymiaru Sprawiedliwości, sygn. 737).

67 „Kto przy wykonywaniu obrzędów lub innych funkcji religijnych nadużywa wolności sumienia i wyznania na szkodę interesów Polskiej Rzeczypospolitej Ludowej, podlega karze pozbawienia wolności od roku do lat 10" - Projekt z 1968 roku..., s. 55).

68 Ibidem, s. 145.

69 Uwagi i zastrzeżenia do projektu kodeksu karnego zgłoszone przez konferencje plenarna Episkopatu Polski na sesje plenarnych Warszawie w dniach 16 do 17 stycznia oraz 22 do 23 stycznia 1968 roku (brak numerów stron) - AAN, Archiwum Władysława Siła-Nowickiego, sygn. 247 (dalej: Uwagi i zastrzeżenia do projektu kodeksu karnego zgłoszone przez konferencje plenarna Episkopatu Polski...).

70 „Kto publicznie lży, wyszydza lub poniża grupę ludności lub poszczególną osobę z powodu jej bezwyznaniowości lub przynależności wyznaniowej, podlega karze pozbawienia wolności do lat 3" Projekt z 1968 roku..., s. 55.

71 Uwagi i zastrzeżenia do projektu kodeksu karnego zgłoszone przez konferencję plenarna Episkopatu Polski... 
Podobne zastrzeżenia, jeżeli chodzi o zbyt wąski zakres przedmiotowy penalizacji, dotyczyły art. 204 projektu $^{72}$. Zdaniem przedstawicieli Kościoła katolickiego przepis ten powinien przewidywać odpowiedzialność za jakiekolwiek znieważenie przedmiotu czci religijnej lub jakiegokolwiek miejsca przeznaczonego do wykonywania obrzędów religijnych bez wymogu znamienia publiczności. W swoim stanowisku podkreślili bowiem, że „w poczuciu prawnym społeczeństwa karalne winno być m.in. znieważenie symbolu religijnego znajdującego się w mieszkaniu prywatnym lub prywatnej kaplicy czy ołtarza, które są przeznaczone do wykonywania obrzędów religijnych, choćby w ściśle zamkniętym gronie"73. Z tych powodów postulowali powrót do art. 173 k.k. z 1932 r., który syntetycznie realizował te postulaty ${ }^{74}$.

Nie do zaakceptowania był również art. 203, ograniczający odpowiedzialność karną za złośliwe przeszkadzanie aktom religijnym jedynie do pogrzebu lub innego obrzędu żałobnego ${ }^{75}$. W swoi stanowisku Episkopat podkreślił, że „dla poczucie prawnego polskiego społeczeństwa, ale również każdego cywilizowanego i kulturalnego społeczeństwa - byłoby rzeczą niezrozumiałą ograniczanie sankcji karnej za złośliwe przeszkadzanie aktom religijnym do obrzędu pogrzebowego, czy procesji żałobnej, przy uznaniu za rzecz karnoprawnie obojętną analogicznego czynu w stosunku do mszy, obrzędu ślubu, chrzcin, czy procesji związanej ze świętem Wielkanocnym lub uroczystością Bożego Ciała"76. W tej sytuacji, zdaniem Episkopatu, powrót do art. 174 k.k. z 1932 r., byłby „wyrazem postępu społecznego i troski Państwa o zabezpieczenie praw obywatela”. Tak się jednak nie stało.

Duchowieństwo odniosło się również do przestępstwa „nadużywania wolności sumienia” (art. 20077) i „wykorzystywania wierzeń celem wprowadzenia w błąd $\left(\operatorname{art.~} 201^{78}\right)$, przeniesionych z art. 8 i art. 9 „Dekretu sierpniowego”. Oba-

72 „Kto obraża uczucia religijne innych osób, znieważając publicznie przedmiot czci religijnej lub miejsce przeznaczone do publicznego wykonywania obrzędów religijnych, podlega karze pozbawienia wolności do lat 2, ograniczenia wolności albo grzywny", Projekt $z 1968$ roku..., s. 55.

73 Uwagi i zastrzeżenia do projektu kodeksu karnego zgłoszone przez konferencje plenarna Episkopatu Polski...

74 „Kto publicznie lży lub wyszydza uznane prawnie wyznanie lub związek religijny, jego dogmaty, wierzenia lub obrzędy, albo znieważa przedmiot jego czci religijnej lub miejsce przeznaczone do wykonywania jego obrzędów religijnych, podlega karze więzienia do lat 3".

75 „Kto złośliwie przeszkadza pogrzebowi lub innemu obrzędowi żałobnemu albo znieważa zwłoki lub prochy ludzkie lub miejsce spoczynku zmarłego, podlega karze pozbawienia wolności do lat 3", Projekt z 1968 roku..., s. 55.

76 Uwagi i zastrzeżenia do projektu kodeksu karnego zgłoszone przez konferencje plenarną Episkopatu Polski...

77 „Kto przy wykonywaniu obrzędów lub innych funkcji religijnych nadużywa wolności sumienia i wyznania na szkodę interesów Polskiej Rzeczypospolitej Ludowej, podlega karze pozbawienia wolności od roku do lat 10", Projekt $z 1968$ roku..., s. 55.

78 „Kto wykorzystując cudze wierzenia religijne lub cudzą łatwowierność w sprawach wiary, wprowadza w błąd inne osoby i powoduje zbiegowisko lub inne zakłócenie porządku publicznego, podlega karze pozbawienia wolności od 6 miesięcy do lat 5", ibidem. 
wy wzbudzała znaczna ogólnikowość tych przepisów, mogąca doprowadzać do ich nadużywania w praktyce, tak jak to miało miejsce dotychczas ${ }^{79}$. Odpowiedź na pytanie dlaczego takie uregulowanie zaproponowano, sprowadzała się do retorycznego, aczkolwiek trafnego stwierdzenia, że „karalne jest jeżeli «funkcje i czynności religijne» zagrażają Polsce Ludowej, a jednocześnie według brzmienia projektu ma pozostać niekaralnym, jako rzekomo nie naruszające interesom Państwa, jeżeli ktokolwiek zagraża spokojnemu wykonywaniu tychże «funkcji i czynności religijnych» przez Kościół lub inny związek religijny" ${ }^{80}$.

Zastrzeżenia ze strony Episkopatu budził również fakt pozbawienia duchownych statusu funkcjonariusza na gruncie projektowanych przepisów prawa karnego (art. $120 \$ 11)^{81}$. Episkopat przypomniał, że do 1939 r. duchowi korzystali ze szczególnej ochrony prawnej na równi z urzędnikami, nie tylko przy pełnieniu czynności ściśle religijnych, lecz także przy sprawowaniu wszelkich obowiązku służby lub powołania ${ }^{82}$. Zdaniem Episkopatu było to tym dziwniejsze, że właśnie na publiczny charakter funkcji duchownych wielokrotnie powoływała się władza jako uzasadnienie wydania dekretu z 31 grudnia 1956 r., o organizowaniu i obsadzaniu stanowisk kościelnych ${ }^{83}$.

Hierarchowie Kościoła katolickiego odnieśli się również do przepisów penalizujących przerwanie ciąży ${ }^{84}$. Wedle propozycji Zespołu Prawa Karnego Materialnego Komisji Kodyfikacyjnej przy ministrze sprawiedliwości, odpowiedzialność karna zależał m.in. od zgody kobiety ciężarnej ${ }^{85}$. A contrario oznaczało to tyle, że zabieg przerwania ciąży za zgodą kobiety ciężarnej i zgodnie z ustawą regulującą szczegółowo warunki i okoliczności jej przeprowadzenia, byłby legalny ${ }^{86}$. Z tego względu Episkopat przypomniał projektodawcom, że ustawodawstwa ZSRR i NRD nie dopuszczają zabiegów przerywania ciąży za zgodą kobiety ciężarnej, za wyjątkiem wypadków przewidzianych w polskim kodeksie karnym z $1932 \mathrm{r}^{87} \mathrm{Z}$ tych powodów, ich zdaniem, zarówno przepisy

79 Uwagi i zastrzeżenia do projektu kodeksu karnego zgłoszone przez konferencję plenarna Episkopatu Polski...

80 Ibidem.

81 Projekt $z 1968$ roku..., s. 33.

82 Uwagi i zastrzeżenia do projektu kodeksu karnego zgłoszone przez konferencje plenarna Episkopatu Polski...

83 (Dz.U. $1957 \mathrm{nr}$ 1, poz. 6).

84 Uwagi i zastrzeżenia do projektu kodeksu karnego zgłoszone przez konferencje plenarna Episkopatu Polski...

85 „Kto przemocą wywołuje poronienie u kobiety ciężarnej albo w inny sposób bez jej zgody przerywa ciąże lub doprowadza ją do tego przemocą, groźbą bezprawną albo podstępem, podlega karze pozbawienia wolności od 6 miesięcy do lat 8" (art. 159), Projekt z 1968 roku..., s. 45.

86 „Kto za zgodą kobiety ciężarnej, lecz wbrew przepisom ustawy, wykonuje zabieg przerwania ciąży, podlega karze pozbawienia wolności do lat 3” (art. $160 \$ 1$ ), ibidem.

87 Zgodnie z art. 233 k.k. z 1932 r., warunkami nieodpowiedzialności za spędzenie płodu były zdrowie kobiety ciężarnej, albo pochodzenie ciąży z przestępstwa, J. Makarewicz, Kodeks karny, wyd. z 1935 roku.... s. 404. 
dotychczasowej ustawy z 27 kwietnia 1956 r., o warunkach dopuszczalności przerywania ciąży ${ }^{88}$, jak i projektowane rozwiązania prawne powinny być uchylone $^{89}$. Ich zdaniem, przemawiały za tym nie tylko przykazania moralności chrześcijańskiej, ale także względy praktyczne w postaci spadku przyrostu populacji PRL. Episkopat podkreślił również, że liberalizm aborcyjny może spowodować zmniejszenie się liczby ludności w Polsce w stosunku do sąsiadów naszego kraju, co byłoby „świadectwem mniejszej prężności społeczeństwa, a akceptacja takiego stanowiska ze strony władzy stanowiłaby przyznanie się do zasadniczej porażki na tym polu"

Hierarchowie Kościoła katolickiego zwrócili także uwagę na ogromny rozwój środków antykoncepcyjnych ${ }^{91}$. Episkopat podkreślił, że z punktu widzenia moralności chrześcijańskiej Kościół wnosi szereg zastrzeżeń, ale nie są one tak kategorycznej i bezwzględnej natury jak przerywanie ciąży, które w pojęciu moralnym człowieka wierzącego jest równoznaczne z zabójstwem. Nie ulega również wątpliwości, że zapobieganie ciąży jest mniej szkodliwe dla organizmu kobiety niż spędzenie płodu ${ }^{92}$.

Jednak to nie stanowisko Episkopatu względem przepisów projektu chroniących życie, czy wolność wyznania zasługują na podkreślenie, bo jest ono od zawsze takie samo, ale diagnoza obrazu ówczesnej rzeczywistości społeczno-politycznej Polski. W dokumencie można bowiem przeczytać, że „zasadniczym problemem ideologicznym PRL jest prawidłowa współpraca pomiędzy niewierzącymi, w których ręku znajduje się kierownictwo polityczne kraju rządząca partia wyznaje światopogląd materialistyczny - a wierzącymi, którzy stanowią większość społeczeństwa polskiego" ${ }^{\text {"3 }}$. Fakt ten, zdaniem Episkopatu, prowadził do niebezpiecznych sprzeczności między prawem a poczuciem moralnych zasad wyznawanych przez większość społeczeństwa. Ta trafna ocena może mieć zastosowanie do całego obrazu PRL oraz wydanych w trakcie jej istnienia przepisów prawa karnego.

\section{O prawnokarnej ochronie wolności sumienia i wyznania na forum Sejmu PRL IV Kadencji}

Problem karnoprawnej ochrony wolności sumienia i wyznania powrócił podczas drugiego i trzeciego czytania projektu kodeksu karnego z 1968 r. w Sejmie PRL IV Kadencji. W trakcie prac w Komisji Wymiaru Sprawiedli-

88 (Dz.U. $1956 \mathrm{nr}$ 12, poz. 61).

89 Uwagi i zastrzeżenia do projektu kodeksu karnego zgłoszone przez konferencje plenarna Episkopatu Polski...

90 Ibidem.

91 Ibidem.

92 Ibidem.

93 Ibidem. 
wości, przeciwko rozwiązaniom projektu w tym zakresie wystąpił Stanisław Stomma. Jego zastrzeżenia budziła większość przepisów z rozdziału XXIX projektu „Przestępstwa przeciwko wolności sumienia i wyznania”. Wnioskował m.in. o skreślenie art. 200 i art. 201 tegoż oraz objęcie ochroną z art. 203 także innych - oprócz pogrzebu - obrzędów religijnych ${ }^{94}$. Poseł „Znak” sugerował członkom Komisji, że te przepisy mają ewidentnie antyklerykalny wyraz, a ich przyjęcie przez nowy k.k. może wywołać ujemny oddźwięk w społeczeństwie ${ }^{95}$. Był również zdania, że rzekoma potrzeba przejmowania rozwiązań z dekretu o ochronie wolności sumienia i wyznania z 1949 r. jest sprzeczna z potrzebami rzeczywistości końca lat 60., czym sugerował odmienną - przychylniejszą względem władzy - postawę kleru ${ }^{96}$. Kazimierz Zawadzki był jednak odmiennego zdania wskazując na wciąż znaczną liczbę spraw sądowych $\mathrm{z}$ tego zakresu $^{97}$.

Propozycje powyższe zostały rozpatrzone na posiedzeniu Komisji Wymiaru Sprawiedliwości w dniu 12 marca 1969 r. ${ }^{98}$ Poprawki posła Reiffa zostały odrzucone. Co ciekawe, poseł Stanisław Stomma, oświadczył - zapewne pod wpływem negatywnej dyskusji - że nie życzy sobie głosowania w przedmiocie jego poprawek dotyczących wolności sumienia i wyznania, które sam uznał za odrzucone ${ }^{99}$. Pozostałe zostały odrzucone w głosowaniu. Autopoprawki rządu zostały przyjęte $\mathrm{e}^{100}$

Losy propozycji S. Stommy przełożyły się na jego postawę w głosowaniu nad wnioskiem o uchwalenie przez Sejm projektu k.k. wraz z przyjętymi przez Komisję poprawkami. Jako jedyny wstrzymał się od głosu ${ }^{101}$. Podczas trzeciego czytania przypomniał z mównicy sejmowej swoje zastrzeżenia co do projektu. Wyraził przekonanie, że pomimo stanowiska władz, są warunki do „harmonijnej koegzystencji" państwa i kościoła, które czynią zbędnym sankcje karne w postaci art. 200 i $201^{102}$. Wypomniał projektodawcom również, jego zdaniem, „unikowe” podejście do zagadnienia przerwania ciąży. W jego ocenie przepis art. 160 stanowiący, że „Kto wbrew przepisom ustawy dokonuje przerwania ciąży...", potwierdzał nazbyt liberalne podejście do ustawy z 1956 r., zamiast

94 Protokół z 49 posiedzenia Komisji Wymiaru Sprawiedliwości Sejmu Polskiej Rzeczypospolitej Ludowej z dnia 12 stycznia 1969 roku, s. 15-16 (AAN, Sejm PRL - IV Kadencja 1965-1969. Protokóły komisji sejmowych. Tom LXXXI. Komisja Wymiaru Sprawiedliwości, sygn. 737).

95 Ibidem.

96 Ibidem.

97 Ibidem, s. 17.

98 Ibidem, s. 2-20.

99 Ibidem, s. 17.

100 Ibidem, s. 15-18.

101 Ibidem, s. 19.

102 Sprawozdanie stenograficzne z 22 posiedzenia Sejmu Polskiej Rzeczypospolitej Ludowej w dniach 18 i 19 kwietnia 1969 roku. Warszawa 1969, s. 69. 
dążyć do ograniczania i tak nadużywanego przerywania ciąży ${ }^{103}$. Pomimo tych zastrzeżeń głosował za uchwaleniem projektu. Był osamotniony w swojej krytyce prawnokarnej „ochrony” wolności sumienia i wyznania w kodeksie karny PRL. Dominujące było bowiem stanowisko, które dobitnie wyraził reprezentant Stronnictwa Demokratycznego poseł Witold Lassota mówiąc, że „Jest zupełnie oczywiste, że w krajach cywilizacyjnie rozwiniętych, a szczególnie w krajach budujących ustrój socjalistyczny, systematycznie i w sposób naturalny postępuje proces laicyzacji życia i zasad społecznych. Konsekwencją tego procesu musi więc być zarówno ochrona kultu religijnego, jak też przeciwdziałanie wszelkiej dyskryminacji niewierzących i niepraktykujących"104.

\section{Zakończenie}

Dyskusja nad projektami kodeksu karnego z lat 1963 i 1968 przyniosła wiele bardzo sugestywnych odniesień do sytuacji społeczno-politycznej okresu PRL. Jest faktem powszechnie znanym, a to również wynika wprost $\mathrm{z}$ projektowanych wówczas przepisów, że partia doskonale zdawała sobie sprawę z praktykowania religii nie tylko przez większość społeczeństwa, ale także przez znaczną część swoich członków, a już bez wątpienia ich rodziny. Zdawała sobie również sprawę, że chcąc wiernie wypełniać ateistyczne założenia ideologii marksistowskiej, skazuje ich na ostracyzm społeczny i problemy w najbliższym otoczeniu. Wiedząc zatem, że tym sposobem związki wyznaniowe, a przede wszystkim Kościół katolicki, sprawują „rząd dusz” nad większością obywateli, chciała go zastraszyć perspektywą odpowiedzialności karnej niemal za wszystko, co byłoby nie pomyśli władzy. „Dekret sierpniowy" był w tym zakresie prekursorem.

Sekretarz Episkopatu bp Z. Chrapoński oraz Jan Olszewski, użyli na określenie powyższego zjawiska pojęcia „fanatyzm”, które dobrze oddaje stosunek antyklerykalny ówczesnej partii komunistycznej.

Mając powyższe na względzie, należy również dojść do przekonania, że na drodze do jakiejkolwiek „pokojowej” koegzystencji władzy komunistycznej z Kościołem katolickim, stał nie tylko programowy ateizm rządzących, ale także fakt, że Kościół katolicki był w zasadzie jedyną niezależną siłą społeczną w Polsce po 1944 r., a to stało w sprzeczności z kształtującą się dyktaturą proletariatu. Dodatkowo Kościół katolicki był i jest niejako od zawsze „depozytariuszem” tych filozoficznie pojętych sfer życia człowieka, które zwykle

103 Ibidem.

104 Ibidem, s. 100. 
wymykają się totalitarnej władzy z rąk, czyli swobody sumienia, myśli i wiary. To siłą rzeczy musiało prowadzić do konfrontacji. Dla rewolucji nie ma bowiem obszarów obojętnych, o ile, jak twierdził Prymas August Hlond, „nie lękamy się ludowej formy rządów ${ }^{105 ”,}$, to nie można tego samego powiedzieć o władzy ludowej i jej stosunku do wiary. Władza miała się czego lękać, albowiem bez opanowania i tej sfery życia społeczeństwa polskiego trudno było mówić o dopełnieniu się rewolucji socjalistycznej i ugruntowaniu nowego porządku ustrojowego.

Smutne w tym wszystkim jednak jest to, że gdzieś po drodze zapomniano o człowieku i jego przyrodzonej wolności sumienia i wyznania, którą potraktowano instrumentalnie do walki. Z tych powodów trudno w ogóle mówić o prawnokarnej „ochronie” wolności sumienia i wyznania skoro ratio legis ówczesnych przepisów było ich zaprzeczeniem i to już na etapie ich opracowywania.

\section{Bibliografia}

\section{Archiwalia}

Pławski S., Uwagi o dekrecie z 5 sierpnia 1949 r. (AAN.MS. sygn. 285/1829).

Wstęp do Założeń społeczno-politycznych k.k.(Wersja III), s. 1 - (AAN, MS, sygn. 285/1844).

Protokół z konferencji pod przewodnictwem Prezesa Rady Ministrów Józefa Cyrankiewicza odbytej $w$ dniu 3 stycznia 1968 roku w sprawie omówienia i rozstrzygnięcia nieuzgodnionych problemów projektu kodeksu karnego (poufne), s. 1-2 (AAN, PZPR Komitet Centralny, sygn. XI/908).

Protokół z 35 posiedzenia Komisji Wymiaru Sprawiedliwości Sejmu Polskiej Rzeczypospolitej Ludowej z dnia 19 kwietnia 1968 roku, s. 7 (AAN, Sejm PRL - IV Kadencja 1965-1969. Protokóły komisji sejmowych. Tom LXXXI. Komisja Wymiaru Sprawiedliwości, sygn. 737).

Uwagi i zastrzeżenia do projektu kodeksu karnego zgłoszone przez konferencje plenarna Episkopatu Polski na sesje plenarna Warszawie w dniach 16 do 17 stycznia oraz 22 do 23 stycznia 1968 roku (brak numerów stron) - AAN, Archiwum Władysława Siła-Nowickiego, sygn. 247.

Protokół z 49 posiedzenia Komisji Wymiaru Sprawiedliwości Sejmu Polskiej Rzeczypospolitej Ludowej z dnia 12 stycznia 1969 roku, s. 15-16 (AAN, Sejm PRL - IV Kadencja 1965-1969. Protokóły komisji sejmowych. Tom LXXXI. Komisja Wymiaru Sprawiedliwości, sygn. 737).

105 A. Nowicz, op. cit., s. 40-41. 


\section{Akty prawne}

Ustawa z dnia 17 marca 1921 r., Konstytucja Rzeczypospolitej Polskiej (Dz.U. 1921 nr 44, poz. 267).

Ustawa z dnia 11 marca 1932 r., o zgromadzeniach (Dz.U. 1932 nr 48, poz. 187).

Dekret z dnia 5 sierpnia 1949 r. o ochronie wolności sumienia i wyznania (Dz.U. 1949 nr 45, poz. 334).

Dekret z dnia 18 sierpnia 1949 r., o zmianie niektórych przepisów o zgromadzeniach (Dz.U. 1949 nr 49, poz. 369).

Konstytucja Polskiej Rzeczypospolitej Ludowej uchwalona przez Sejm Ustawodawczy w dniu 22 lipca 1952 r. (Dz.U. 1952 nr 33, poz. 232).

Ustawa z 27 kwietnia 1956 r., o warunkach dopuszczalności przerywania ciąży (Dz.U. $1956 \mathrm{nr} 12$, poz. 61).

Dekret z 31 grudnia 1956 r., o organizowaniu i obsadzaniu stanowisk kościelnych (Dz.U. 1957 nr 1, poz. 6).

Ustawa z dnia 31 stycznia 1961 r., o łączności (Dz.U. 1961 nr 8, poz. 48).

Ustawy z dnia 10 lutego 1976 r. o zmianie Konstytucji Polskiej Rzeczypospolitej Ludowej (Dz.U. 1976 nr 5, poz. 29).

Uchwała Prezydium Rządu z dnia 27 września 1950 r., w sprawie opracowania nowych kodeksów Polski Ludowej - karnego i cywilnego (Mon. Pol. 1950, nr A-106, poz. 1339).

\section{Literatura}

Dembiński L., Prawo i władza. „Niezależna Oficyna Wydawnicza” (Przedruk z „Aneks” 1979, nr 20).

Grzybowski K., Reform and Codification of Polish Laws, „The American Journal of Comparative Law" 1958, t. 7, nr 3;

Kienzler I., Kronika PRL 1944-1989, t. 27. Kościół w PRL, Warszawa 2016.

Kochanowski J., Przeciwko pośpiesznej kodyfikacji karnej, „Palestra” 1990, t. 34, nr 8-9.

Kochanowski J., Redukcja odpowiedzialności karnej (Analiza i ocena założeń kodeksu karnego z 1997 na tle innych polskich kodyfikacji karnych). Komentarz, Warszawa 2000.

Kolczyński J., Projekt kodeksu karnego. Sześć pytań, „Prawo i Życie” 1963, nr 2.

Lepiej niech teraz nie śpia... Spór o paragraf, „Sztandar Młodych”, nr 49.

Łysko M., Kolegia karno-administracyjne w walce $z$ Kościołem katolickim w Polsce (1956-1970), „Czasopismo Prawno-Historyczne” 2007, z. 1.

Makarewicz J., Kodeks karny z komentarzem, Lwów 1938 (reprint Lublin 2012).

Makarewicz J., Kodeks karny z komentarzem, Lwów 1935.

Maksimiuk D., Krótka historia długo obowiązującego dekretu, czyli o tzw. małym kodeksie karnym. „Miscellanea Historico-Iuridica” 2010, t. IX.

Mazur M., ZPP a dyskusja nad projektem k.k., „Prawo i Życie” 1963, nr 4.

Mioduski K., Technika, kodyfikacja a moda, „Prawo i Życie” 1963, nr 5. 
Nowicz A., Stosunki Kościół-Państwo w Polsce 1944-55 (Szkic zagadnienia), Poznań 1984.

Olszewski J., Blaski i nędze kodyfikacji - Zasady kodeksu i logika życia, „Prawo i Życie” 1963, nr 3.

Olszewski J., K.k., i fantazja, „Nowa Kultura” 1963.

Podgórecki A., Krytyka metodologicznych założeń projektu kodeksu karnego, „Państwo i Prawo" 1963, nr 4.

Podsiadło W., Nad projektem kodeksu karnego (2) - paragrafy i życie, „Głos Szczeciński” 1963, nr 86.

Projekt kodeksu karnego w ocenie przedstawicieli wymiaru sprawiedliwości Łodzi i województwa. Narada w KW PZPR, „Głos Robotniczy” 1963, nr 78.

Projekt nowego kodeksu karnego wchodzi pod publiczna dyskusję, „Trybuna Ludu” 1963, nr 18.

Reperowicz S., Obywatel w cieniu paragrafów, „Żołnierz Wolności”, wyd. A 1963, nr 61.

Rozpoczyna się publiczna dyskusja nad projektem nowego kodeksu karnego, „Express Wieczorny" 1963, nr 15.

Rybicki R., Informacja o stanie prac kodyfikacyjnych i o przebiegu dyskusji nad projektem kodeksu karnego (do użytku wewnętrznego), AAN, MS, sygn. 285/1792.

Żaryn J., Kościół w PRL, Warszawa 2004.

\section{Inne}

Makarewicz J., Prawo karne i prawa obywatela (Odczyt wygłoszony w dniu 20 stycznia 1936 roku w Auli Uniwersytetu J. K. we Lwowie w czasie Akademii w związku z 275. rocznicą założenia tegoż Uniwersytetu) s. 101 (http://www.khpp.wpia. uj.edu.pl/documents/106750129/137607143/Juliusz+Makarewicz\%2C +Prawo+karne+i+prawa+obywatela\%2C+Lwów+1936.pdf/199928e0-6385-44a7ba0e-a51d568af32b, ( 10.08.2019).

Projekt kodeksu karnego oraz przepisów wprowadzających kodeks karny, Warszawa 1968.

Komisja Kodyfikacyjna przy Ministrze Sprawiedliwości, Projekt kodeksu karnego, Warszawa 1963.

Pismo Sekretarza Episkopatu Polski ba Zygmunta Choromańskiego z dnia 9 maja 1963 r. do ministra sprawiedliwości Mariana Rybickiego w sprawie uwag do projektu kodeksu karnego, s. 2, AAN, MS, sygn. 564.

Sprawozdanie stenograficzne z 22 posiedzenia Sejmu Polskiej Rzeczypospolitej Ludowej w dniach 18 i 19 kwietnia 1969 roku, Warszawa 1969, s. 69.

Skoczeń A., Wolność sumienia $i$ wyznania $w$ świetle orzecznictwa Sądu Najwyższego w Polsce Ludowej, Rozprawa doktorska obroniona w 2019 r. w Akademii Leona Koźmińskiego w Warszawie, napisana pod kierunkiem Prof. ALK dr hab. Marzeny Dyjakowskiej; sygn. 208. DR. Sko.2019. 


\section{STRESZCZENIE}

\section{Kwestia „ochrony” wolności sumienia i wyznania w toku prac nad kodyfikacją prawa karnego Polskiej Rzeczypospolitej Ludowej 1949-1969}

Prawnokarna ochrona wolności sumienia i wyznania w Polsce Ludowej, to zagadnienie, które zasługuje na szczególne zainteresowanie. Po pierwsze, dlatego, że stanowi jedno z głównych zagadnień problemowych - podjętego na początku lat 50. XX w. - dzieła kodyfikacji prawa karnego materialnego PRL, która dotychczas nie doczekała się całościowego opracowania. Po drugie, dlatego że ukazuje ona walkę ówczesnej władzy komunistycznej ze związkami wyznaniowymi, a w szczególności z Kościołem katolickim. Wydane w okresie Polski Ludowej akty prawne, a przede wszystkim okoliczności wydaniu towarzyszące, ponad wszelką wątpliwość dowodzą, że ówczesna władza traktowała w tym zakresie prawo karne instrumentalnie. Chodziło bowiem przede wszystkim o spacyfikowanie związków wyznaniowych pod względem ich potencjalnego oddziaływania na opinię publiczną. Rzekoma potrzeba ochrony praw osób bezwyznaniowych była z kolei wyrazem obaw władz komunistycznych o sytuację społeczną swoich członków i ich rodzin, którzy poddawani byli coraz szerszemu ostracyzmowi ze strony przedstawicieli i członków wspólnot wyznaniowych, w tym Kościoła katolickiego. Kościół katolicki w Polsce nie pozostawał obojętny na proces przekształcania prawa karnego materialnego według założeń komunistycznych. Potwierdza to znany fakt, że pomimo represji jego przedstawiciele pozostawali nieugięci w swojej postawie, jeśli chodzi o wyznawane wartości. Nie było bowiem z ich strony zgodny na kreowanie nowego typu moralności i światopoglądu Polaka na podstawie ateistycznych założeń ideologii marksistowskiej oraz walkę z Kościołem przy użyciu norm prawa karnego. Pomimo zdecydowanej postawy Kościoła katolickiego, postanowienia kolejnych projektów kodeksu karnego PRL pozostawały w zakresie prawnokarnej ochrony wolności sumienia i wyznania niezmienione. Władza postrzegała bowiem niezależną działalność tej instytucji jako zagrożenie, stąd nie tylko chęć jej zwalczania przy pomocy przepisów traktujących o „działaniu na szkodę PRL”, ale także marginalizowanie religii i związanych z nią obrzędów na gruncie prawa karnego.

\section{SUMMARY}

The issue of "protection" of freedom of conscience and religion in the course of work on codification of criminal law of the Polish People's Republic 1949-1969

The protection of freedom of conscience and religion in the criminal law of the Polish People's Republic deserves special interest. Firstly, because it is one of the main problems of criminal law codifications in the Polish People's Republic, which had not been yet fully compiled. Secondly, because it's shows the struggle of the 
then communist authorities against religious associations, especially against the Catholic Church. Legal acts issued during the People's Republic of Poland period, and above all the circumstances, clearly prove that the authorities at that time treated criminal law instrumentally. Criminal law was needed to pacify religious associations in terms of their potential impact on public opinion. The alleged need to protect non-denominational people was only an excuse for authorities to fight against the ostracism of their members in the Catholic Polish society. The Catholic Church in Poland was not indifferent to the process of transforming the criminal law according to communist assumptions, despite many repressions of its members. They were against the creation of a new type of morality and worldview of a Pole based on the atheistic assumptions of Marxist ideology and the fight against the Church using criminal law norms. Despite the strong attitude of the Catholic Church, the provisions of subsequent draft criminal codes of the Polish People's Republic remained unchanged in the scope of criminal and legal protection of freedom of conscience and religion. The authorities perceived the institution's independent activity as a threat, hence not only the desire to combat it with the provisions dealing with «acting to the detriment of the PRL», but also marginalizing religion and related rites under criminal law. 